\title{
Being a Student Nurse in Neurosurgical Intensive Care Unit: A Qualitative Study
}

\author{
Nöroşirurji Yoğun Bakım Ünitesinde Öğrenci Hemşire Olmak: \\ Nitel Bir Çalışma
}

\author{
Serpil YÜKSEL $\odot$, Gülay ALTUN UĞRAŞ $\odot$
}

\section{ABSTRACT}

Objective: The aim of this study was to determine the perceptions, thoughts and clinical experiences of second-year nursing students about a neurosurgical intensive care unit (ICU). Method: The population of this phenomenological qualitative study consisted of 21 second-year nursing students who received clinical training in a neurosurgical ICU of a university hospital. Data were collected by face-to-face and in-depth interviews in June 2018. Data were analyzed using inductive content analysis, and 60 codes, 14 categories and five themes emerged in the data analysis.

Results: The mean age of the participants, most of whom were female students, was 20.7 years. The clinical training period of the majority of the students was three days. It was determined that the ICU environment, status of patients, attitudes of nurses and applied care interventions affected their clinical experience. The students stated that witnessing the death of a patient, not being able to communicate with an unconscious patient, and care interventions such as oral care and aspiration affected them emotionally. The majority of the students indicated that neurosurgical ICU was an essential area for clinical training and they wanted to work in this unit after graduation.

Conclusion: The results of the research revealed that neurosurgical ICU is an important and useful clinical environment for nursing education, but in this unit, some students experience severe anxiety that negatively affects their professional self-esteem.

Keywords: Clinical training, qualitative study, neurosurgical intensive care unit, student nurse

$$
\text { Öz }
$$

Amaç: Bu araştırmada, hemşirelik ikinci sınıf öğrencilerinin Nöroşirürji Yoğun Bakım Ünitesi'ne (YBÜ) ilişkin algılarını, düşüncelerini ve klinik deneyimlerini belirlemek amaçlandı.

Yöntem: Fenomolojik tipteki bu kalitatif araştırma, bir üniversite hastanesinin nöroşirurji YBÜ’nde klinik eğitim alan 21 ikinci sınıf hemşirelik öğrencisi ile gerçekleştirildi. Araştırma verileri, yüz yüze ve derinlemesine bireysel görüşme yöntemi ile Haziran 2018 tarihinde toplandı. Veriler tümevarımcı içerik analizi ile değerlendirildi, 60 kod, 14 kategori ve beş tema belirlendi.

Bulgular: Çoğunluğunu kız öğrencilerin oluşturduğu katılımcıların yaș ortalaması 20.7 yıldı. Öğrencilerin çoğunluğunun klinik eğitim süresi üç gündü. Klinik deneyimi, YBÜ ortamının, hastaların durumunun, hemşirelerin tutumunun ve uygulanan bakım girişimlerinin etkilediği belirlendi. Öğrenciler, hastanın ölümüne tanıklık etmenin, bilinci kapalı hasta ile iletişim kuramamanın, ağız bakımı ve aspirasyon gibi bakım girişimlerinin kendilerini duygusal olarak etkilediğini ifade etti. Öğrencilerin çoğunluğu nöroşirurji YBÜ’nin klinik eğitim için gerekli olduğunu ve mezuniyet sonrası bu ünitede çalışmak istediğini belirtti.

Sonuç: Araştırma, nöroşirurji YBÜ'nin hemşirelik eğitimi için önemli ve yararlı bir klinik ortam olduğunu, ancak bu ünitede bazı ögrrencilerin mesleki özgüvenlerini olumsuz etkileyecek ciddiyette anksiyete yaşadığını ortaya koydu.

Anahtar kelimeler: Klinik eğitim, nitel çalışma, nöroşirürji yoğun bakım ünitesi, öğrenci hemşire
Alındığı tarih: 20.04 .2020

Kabul tarihi: 11.06 .2020

Yayın tarihi: 31.08 .2020

Atıf vermek için: Yüksel S, Altun Ugras G. Being a student nurse in neurosurgical intensive care unit: $A$ qualitative study. Jaren. 2020;6(2):331-40.

Serpil Yükse

Necmettin Erbakan Üniversitesi, Hemşirelik Fakültesi, Hemşirelik Bölümü, Cerrahi Hastalıkları Hemşireliği Anabilim Dalı, Konya - Türkiye

yukselserpil1977@gmail.com ORCID: 0000-0001-6881-8288

G. Altun Uğraş 0000-0001-6804-5035 Mersin Üniversitesi, Hemşirelik Fakültesi, Cerrahi Hastalıkları Hemşireliğ Anabilim Dalı, Mersin, Türkiye

(c) Copyright Association of Publication of the Gaziosmanpas Training and Research Hospital. 


\section{INTRODUCTION}

Nursing education aims to equip students with the knowledge, skills, attitudes and self-esteem they will need while performing nursing profession (1-4). Nursing students acquire professional qualifications through education offered in school and clinical settings ${ }^{(5-8)}$. Internalization of the powers, roles and responsibilities of nursing by students through receiving a qualified education ${ }^{(2,6,9)}$ is significant for professionalization in nursing ${ }^{(1,6,7)}$. Clinical training is an essential part of professional nursing education since it ensures the transformation of the knowledge gained through theoretical education into skills, equips students with empathic approach and critical decision-making and effective communication skills, and allows for observing and applying nursing care interventions ${ }^{(3,4,7,10-13)}$.

One of the crucial clinical training settings that help students prepare for the profession is intensive care units (ICU) $(2,9,11-14)$. In these units, students get the opportunity to identify, implement and assess nursing care needs of critical patients, and to observe team collaboration and communication (2,4,10-14). In one of these units, the neurosurgical ICU, students can serve and provide care to neurosurgical patients with different medical monitoring and care needs ${ }^{(3,8)}$. It is vital that nursing students feel safe in these complex and stressful units ${ }^{(2,7)}$. However, factors such as complex care interventions applied, fear of doing wrong, negative attitudes of nurses, and shortage of faculty members can cause students to experience stress and affect their ICU experience negatively ${ }^{(4,11-13)}$. However, evidence suggests that clinical training in line with the goals of nursing education improves students' technical skills and critical thinking skills, increases their professional self-esteem, and positively affects their perspective on the nursing profession ${ }^{(2,4,7,11)}$. For this reason, ICU experiences of student nurses should be determined and necessary arrangements and improvements should be made in line with the findings obtained.

On the other hand, the majority of studies investigating students' experiences in critical care settings focus on general ICU experience ${ }^{(2,4,7,9-12)}$ and do not provide information about experience in specialized units such as the neurosurgical ICU. Although few in number, the existing studies suggest that the support given to students by neurosurgical nurses ${ }^{(8)}$ and teaching offered by nurses for the care of neurosurgical patients in the presence of real life conditions ${ }^{(3)}$ positively affect the clinical experience ${ }^{(8)}$ and increase students' knowledge, skills and self-esteem ${ }^{(3)}$. In the light of these points, the aim of this study was to determine the perceptions, thoughts and clinical experiences of second- year nursing students about the clinical training in an ICU. The results to be obtained from this study could guide the review of clinical training objectives, the solution of problems that adversely affect clinical training, and the restructuring of the neurosurgical ICU as an employment area favored by newly graduated nurses.

\section{METHOD}

\section{Research Design, Population and Sample}

The study used a phenomenological qualitative study design. The study population consisted of 28 secondyear nursing students who received clinical training as a part of Surgical Diseases Nursing course in the neurosurgical ICU of a university hospital between February 19 and May 31, 2018. Students who skipped clinical training classes $(n=3)$ or refused to participate in the study $(n=4)$ were excluded from the study. Therefore, the study was conducted with 21 students.

\section{Data Collection Tools and Data Collection}

Data were collected using a demographic characteristics form and a semi-structured interview form designed by the researchers in line with the literature ${ }^{(2-6,8,10-14)}$. The demographic characteristics form consisted of four questions to determine descriptive characteristics such as age, gender of the students, and duration of clinical training. The semi-structured interview form included 11 open-ended questions.

Data were collected between June 1 and June 15, 2018 by face-to-face and individual in-depth interview method after the students completed their clinical training in the neurosurgical ICU. The individual in-depth interview sessions were conducted on days and at times that were convenient for the students, and each session lasted for 30 minutes on average. At the beginning of the interview sessions, the students were given a copy of the demographic charac- 
teristics form to fill in. The interviews were conducted one by one with the students and the researchers took written notes during the interviews.

\section{Data Analysis}

The participants' demographic data were analyzed using frequency, mean and standard deviation. Data obtained from the individual in-depth interview sessions were analyzed using an inductive content analysis approach ${ }^{(15,16)}$. Firstly, the notes that were taken during the interview were read several times by the researchers. The formulated meanings were organized and conceptualized, and then codes, categories and themes were determined. In order to determine whether the categories represented the themes and, therefore, to ensure the validity and reliability of the study, expert opinion was sought from three faculty members with research experience in qualitative research and clinical practice. The emerging codes, categories and themes and the opinions of the experts were compared (15-17). Finally, after the number of agreement and disagreement areas was determined, the codes, categories and themes with inter-coder agreement of $\geq 90 \%$ were accepted ${ }^{(17)}$.

\section{Limitations of the Study}

The most important limitations of this study are that it was conducted with second-grade nursing students with little clinical training experience and that these students received clinical training in an ICU for the first time. Therefore, the students may not have noticed the differences of the neurosurgical ICU and the details of care given to critical neurosurgical patients. Future research with fourth grade students with different ICU experiences could compare the experiences in a neurosurgical ICU and those in other ICUs and to further evaluate its contribution to clinical training.

\section{Ethical Approach}

This study was carried out in accordance with the ethical principles specified in the Declaration of Helsinki. The research data were collected after obtaining the ethics committee permission (Date/ Number=2018/1389). The students were informed about the aim of the study, and explained that participation in the study was voluntary, then their verbal and written consent was obtained.

\section{RESULTS}

The median age of the participants, most of whom were female students $(n=19)$, was 20.7 years. The ICU clinical training period of 12 students was three days (Table 1$)$. The majority of the students $(n=17)$ indicated that clinical training in this unit was useful and they were willing to work in this unit after graduation ( $n=16)$. Regarding the students' perceptions, thoughts and experiences about the neurosurgical ICU, a total of 60 codes, 14 categories and five themes emerged in the data analysis (Table 2).

\section{Theme 1: Perceptions}

"The atmosphere made me a little nervous. The patients lay unconsciously as if they were dead. The

Table 1. Descriptive Characteristics of the Students.

\begin{tabular}{|c|c|}
\hline Characteristics & Students \\
\hline \multicolumn{2}{|c|}{ Age group (Mean: $20.7 \pm 1.06$ years, $19-23$ years) } \\
\hline$<21$ years (9 Ss) & S3, S5, S6, S8, S9, S10, S11, S12, S15 \\
\hline$\geq 21$ years (12 Ss) & S1, S2, S4, S7, S13, S14, S16, S17, S18, S19, S20, S21 \\
\hline \multicolumn{2}{|l|}{ Gender } \\
\hline Female (19 Ss) & S3, S4, S5, S6, S8, S9, S10, S11, S12, S13, S14, S15, S16, S18, S19, S20, S21 \\
\hline Male (2 Ss) & S1, S2 \\
\hline \multicolumn{2}{|c|}{ Duration of clinical training } \\
\hline 3 days (12 Ss) & $\mathrm{S} 1, \mathrm{~S} 4, \mathrm{~S} 6, \mathrm{~S} 7, \mathrm{~S} 8, \mathrm{~S} 10, \mathrm{~S} 11, \mathrm{~S} 12, \mathrm{~S} 14, \mathrm{~S} 16, \mathrm{~S} 17, \mathrm{~S} 20$ \\
\hline 5 days (9 Ss) & S2, S3, S5, S9, S13, S15, S18, S19, S21 \\
\hline \multicolumn{2}{|c|}{ Necessity of this unit for clinical training in the second year } \\
\hline Necessary (17 Ss) & S2, S4, S6, S8, S9, S10, S11, S12, S13, S14, S15, S16, S18, S19, S20, S21 \\
\hline Unnecessary (4 Ss) & S1, S3, S5, S11 \\
\hline \multicolumn{2}{|c|}{ Willingness to work in this unit after graduation } \\
\hline Willing (16 Ss) & $\mathrm{S} 1, \mathrm{~S} 2, \mathrm{~S} 4, \mathrm{~S} 5, \mathrm{~S} 6, \mathrm{~S} 7, \mathrm{~S} 8, \mathrm{~S} 9, \mathrm{~S} 12, \mathrm{~S} 14, \mathrm{~S} 15, \mathrm{~S} 16, \mathrm{~S} 17, \mathrm{~S} 18, \mathrm{~S} 20, \mathrm{~S} 21$ \\
\hline Unwilling (5 Ss) & S3, S10, S11, S13, S19 \\
\hline
\end{tabular}

S: Student 
nurses were very knowledgeable and experienced (S3)". "The atmosphere was a bit distressing. The patients looked bad. However, I think it is the most useful place to learn about care (S6)". "There were patients who were connected to multiple devices and equipment and needed serious care. However, the nurses were not attentive enough (S8)". "It was a disturbing environment. None of the patients were awake. It was impossible to communicate. I think the communication of the nurses was inadequate, too (S10)". "The environment was overwhelming for me. There were a lot of sounds and many devices that made me nervous. The nurses were inattentive (S18)"." The nurses looked tired, exhausted." (S19).

These statements of the students showed that on their first day of clinical training, they perceived the ICU atmosphere as a disturbing environment with different devices and sounds where they could learn about care. They also considered ICU patients as individuals who were unconscious, in bad shape in terms poor general condition, in need of care and unable to communicate; and that they considered the nurses to be knowledgeable but inattentive (Table 2).

\section{Theme 2: Emotional Effects}

"The struggle for life and death of my 17-year-old patient affected me deeply (S2)". "It was the first death I had ever seen (S3)". "I was extremely moved by a patient who passed away. I was shocked (S13)". "Together with the nurse, I removed a patient's clothes and cleaned her body. It was the first time that I had ever approached a dead person. It was a distressing experience, but I learned a lot (S21)". "This patient with a subdural hematoma affected me. He got worse and worse before my eyes and there was nothing I could do (S6)"."There was this young pati-

Table 2. Themes, Categories and Codes.

\begin{tabular}{|c|c|c|c|c|}
\hline Themes & Categories & & Codes & \\
\hline $\begin{array}{l}\text { Theme 1: } \\
\text { Perceptions }\end{array}$ & $\begin{array}{l}\text { Features of the environment } \\
\text { Patients' condition } \\
\text { Nurses' characteristics }\end{array}$ & $\begin{array}{l}\text { - distressing }(n=18) \\
\text { - different sounds }(n=18) \\
\text { - unconscious }(n=20) \\
\text { - poor general condition } \\
\text { ( } n=20) \\
\text { - knowledgeable }(n=11) \\
\text { - inattentive }(n=6)\end{array}$ & $\begin{array}{l}\text { - various devices ( } n=14) \\
\text { - useful in learning care }(n=13) \\
\text { - in need of care }(n=20) \\
\text { - connected to multiple } \\
\text { devices }(n=18) \\
\text { - inadequate }(n=4) \\
\text { - attentive }(n=2)\end{array}$ & $\begin{array}{l}\text { - clean }(n=12) \\
\text { - cold }(n=9) \\
\text { - unable to communicate } \\
(n=18) \\
\text { - young }(n=10) \\
\text { - tired }(n=2) \\
\text { - exhausted }(n=2)\end{array}$ \\
\hline $\begin{array}{l}\text { Theme 2: } \\
\text { Emotional } \\
\text { effects }\end{array}$ & $\begin{array}{l}\text { Patients' condition } \\
\text { Care interventions }\end{array}$ & $\begin{array}{l}\text { - death of a patient }(n=7) \\
\text { - deteriorating general } \\
\text { condition }(n=6) \\
\text { - bed bath }(n=17) \\
\text { - aspiration }(n=11)\end{array}$ & $\begin{array}{l}\text { - patients' attempts to } \\
\text { communicate through their } \\
\text { eyes }(n=3) \\
\text { - oral care for intubated } \\
\text { patients }(n=8) \\
\text { - pressure sore care }(n=6)\end{array}$ & $\begin{array}{l}\text { - being young }(n=3) \\
\text { - being in pain }(n=2) \\
\text { - perineal care }(n=5) \\
\text { - patient positioning }(n=5)\end{array}$ \\
\hline $\begin{array}{l}\text { Theme 3: } \\
\text { Communication }\end{array}$ & $\begin{array}{l}\text { Student-patient communication } \\
\text { Nurse-patient communication } \\
\text { Student-nurse communication }\end{array}$ & $\begin{array}{l}\text { - inability to communicate } \\
\text { with an unconscious } \\
\text { patient }(n=11) \\
\text { - inadequate }(n=6) \\
\text { - informative }(n=16)\end{array}$ & $\begin{array}{l}\text { - difficulty in communication } \\
(n=11) \\
\text { - communication through } \\
\text { eyes }(n=2) \\
\text { - unilateral }(n=5) \\
\text { - nice }(n=14)\end{array}$ & $\begin{array}{l}\text { - comfortable communication } \\
\text { with conscious patients } \\
(n=4) \\
\text { - good }(n=3) \\
\text { - motivating }(n=9)\end{array}$ \\
\hline $\begin{array}{l}\text { Theme 4: } \\
\text { Contribution to } \\
\text { clinical training }\end{array}$ & $\begin{array}{l}\text { Putting theoretical knowledge } \\
\text { into practice } \\
\text { Professional gain }\end{array}$ & $\begin{array}{l}\text { - effective }(n=13) \\
\text { - increase in professional } \\
\text { knowledge }(n=21)\end{array}$ & $\begin{array}{l}\text { - partially effective }(n=5) \\
\text { - positive effect on perception } \\
\text { of the profession }(n=14)\end{array}$ & $\begin{array}{l}\text { - no effect }(n=3) \\
\text { - increase in self-esteem }(n=2)\end{array}$ \\
\hline $\begin{array}{l}\text { Theme 5: } \\
\text { Opinions }\end{array}$ & $\begin{array}{l}\text { Neurosurgical intensive care } \\
\text { unit nursing } \\
\text { Qualities that neurosurgical } \\
\text { intensive care unit nurses } \\
\text { should possess } \\
\text { Necessity as a clinical training } \\
\text { area } \\
\text { Willingness to work in } \\
\text { neurosurgical intensive care } \\
\text { unit after graduation }\end{array}$ & $\begin{array}{l}\text { - a demanding profession } \\
(n=8) \\
\text { - knowledge }(n=13) \\
\text { - critical thinking }(n=10) \\
\text { - swift decision-making } \\
\text { ( } n=12) \\
\text { - necessary }(n=17) \\
\text { - willing }(n=16)\end{array}$ & $\begin{array}{l}\text { - too many responsibilities }(n=7) \\
\text { - compassion }(n=9) \\
\text { - attention }(n=7) \\
\text { - enthusiasm for the } \\
\text { profession }(n=7) \\
\text { - unnecessary }(n=4) \\
\text { - unwilling }(n=5)\end{array}$ & $\begin{array}{l}\text { - giving active care }(n=5) \\
\text { - care }(n=6) \\
\text { - ability to empathize }(n=4)\end{array}$ \\
\hline
\end{tabular}


ent. I was deeply affected by him. He was trying to tell me something with his eyes, but he couldn't (S11)".

These statements showed that deteriorating patient condition and loss of a patient emotionally affected the students. The students also mentioned the care interventions that affected them the most as giving body care, performing aspiration, giving oral care to intubated patients and providing pressure sore care (Table 2).

"The care interventions that affected me were certainly aspiration and bed bath (S3)". "Giving oral care to an intubated patient affected me (S4)". "I helped the nurse to perform oral care. The patient was intubated. I was so nervous that I would hurt the patient, and the patient's unconscious state made me feel even more tense (S6)". "The bed bath affected me. For the first time in my life, a naked patient was there in front of me (S11)". "The nursing care that affected me most was pressure sore care (S14)".

\section{Theme 3: Communication}

The following statements showed that the students were unable to communicate with unconscious patients and had difficulty in communicating with conscious but intubated patients and that they considered the nurses' communication with patients as inadequate (Table 2).

"I tried to communicate with the patients. But I had a hard time. The nurses also communicated unilaterally. Only the nurses were talking, and intubated patients were giving signals with their eyes (S2)". "There was no way to communicate with the patients (S6)". "I communicated with an intubated patient through eye contact (S9)". "I was not able to communicate with the patients. They were unconscious (S15)". "I tried to communicate by calling their names. I had difficulty particularly with patients connected to the respirator. The nurses communicated with these patients in the same way... by calling out their names (S17)".

Making the following statements, the students defined the communication of nurses with themselves as instructive, good and motivating (Table 2).
"The nurses were very nice. They were informative (S5)". "The nurses were very good. They told and demonstrated how to provide care to patients. This motivated me" (S14). "They gave very good answers to my questions. I learned a lot. My professional knowledge has increased (S16)".

\section{Theme 4: Contribution to Clinical Training}

The students stated that clinical training in the neurosurgical ICU was effective in transmitting theoretical knowledge into practice, their professional knowledge increased and their perspective on the profession changed positively after this education (Table 2).

"Here, I was able to put my knowledge into practice (S5)". "I believe I managed to reflect what I have learned in the lessons on patient care here (S17)". "I have learned a lot in this intensive care unit $(\mathrm{S} 3, \mathrm{~S} 8)^{\prime \prime}$. "I was going through a time when I questioned my profession. Now, I understand how important my profession is after giving care for patients here (S9)". "Giving care without any help made me feel professional and increased my self-esteem. I feel free here (S18)". "It was the first time I genuinely wanted to be a nurse. Then I said I would be one (S12)". "My professional knowledge has developed here. Now I love my job more (S20)".

\section{Theme 5: Opinions}

The students defined neurosurgical ICU nursing as a nursing specialization that is demanding and requires taking too many responsibilities and giving active care. They stated that a neurosurgical ICU nurse should be knowledgeable and possess critical thinking and swift decision-making skills. The majority of the students stated that they wanted to work in the neurosurgical ICU after graduation (Table 2).

"Neurosurgical intensive care nursing requires a lot of labor, patience and responsibility. Honestly, I would not want to work here (S3)". "A neurosurgical ICU nurse should be able to think critically. I would like to work here after graduation (S7)". "Care interventions are very intense. There are too many responsibilities. I would not want to work here (S10)". "It's hard to be a nurse here. It is required to know the profession well. I would like to work in a unit where I can communicate with the patient (S11)". "Any nurse to work here should be empathetic. I 
would like to work here in the future (S19)".

The majority of the students ( $n=17)$ stated that they have believed that this unit is an essential specialization in second grade nursing training.

"It is certain that the unit contributes a lot to the student. I think every nursing student should spend some time in this unit $(\mathrm{S} 2, \mathrm{~S} 4)$ ". "It definitely is necessary. This unit offers many opportunities to learn and apply nursing care (S14, S20)".

\section{DISCUSSION}

This qualitative study aimed to investigate the perceptions, thoughts and experiences of second-year nursing students about a neurosurgical ICU. The results showed that the majority of the students thought that this unit was useful for clinical training and they wanted to work in this unit after graduation despite the feelings of uneasiness and inadequacy they had experienced in the ICU.

The physical environment of intensive care units is different from other clinical areas ${ }^{(2,11-13)}$. On the first day of the clinical practice, the students considered the neurosurgical ICU as a distressing unit with different sounds and devices where unconscious patients in need of care are treated. Similarly, previous studies showed that student nurses focused primarily on the general condition of patients in an ICU ${ }^{(4,9)}$ and nurses' effort to communicate with patients ${ }^{(4)}$. They found the ICU environment stressful, and the devices and equipment used in treatment and care increased the stress level ${ }^{(4,9,12)}$. Also, Taştan et al. ${ }^{(11)}$ found that students defined ICU as depressing environments with constant monitor sounds and alarms and they mentioned the feelings of fear and panic created by the environment saying, "I was terrified by the sounds of mechanical ventilators, to which patients were connected for breathing, and I panicked when the alarm sounded". It is important to inform students about the neurosurgical ICU environment, the patients treated in this unit and their conditions, regular care interventions, the technological devices used and their intended use as this will reduce anxiety on the first day ${ }^{(8,11)}$. In addition, introducing students to the nurses they will work with in the unit, informing students about the learning objectives expected from them and assuring them that they can contact the instructor whenever they need, could also reduce students' anxiety.

Offering a rich learning environment to nursing students, ICUs are units where students get the opportunity to apply different care interventions such as tracheostomy and wound care and to develop their clinical reasoning skills by actively taking the responsibility for a patient ${ }^{(4,8,10-13)}$. These units offer students the opportunity to learn the duties and responsibilities of a professional nurse ${ }^{(2,10,13,14)}$. In one study, the students emphasized the importance of patient care responsibility in clinical training by saying, "Taking care of a patient is a valuable opportunity to acquire the required knowledge and skills" ${ }^{(10)}$. Kandeel and Ahmed ${ }^{\left({ }^{9}\right)}$ reported that $95.5 \%$ of the students considered ICUs as units that provide the opportunity to provide care to patients. In the neurosurgical ICU, one of specialized ICUs, students also care for patients with different needs and conditions (3) and learn different interventions such as evaluation of consciousness, pupillary responses and intracranial pressure monitoring. In one study, the students described the care that they gave to critical neurosurgical patients saying, "It was a pleasant experience to care for a patient", "I tied up the patient's hair" and "I gave oral care" (4). Similarly, in this study, the students defined the neurosurgical ICU as an environment where nursing care can be learned and said, "The most useful place for learning care", "I have learned a lot" and "giving care without any help made me feel professional". However, the students also considered neurosurgical intensive care nursing as a profession with too many responsibilities and active care duties. These statements are important, demonstrating that student nurses are aware of the caring role of nursing in meeting patients' care needs. These statements are also significant because student nurses usually focus on learning clinical routines and medical technology in ICUs and overlook the caring role of nursing ${ }^{(8)}$. Therefore, in clinical training, students should definitely be given responsibility for patients so that they can realize that care skills are as essential as technological skills.

Intensive care units are challenging environments, both intellectually and emotionally ${ }^{(4,9,13,14)}$. Students 
experience severe anxiety because of the complexity of these units, the use of advanced technological devices in patient care, the general conditions of patients and the fear of doing something wrong or harming the patient due to the lack of knowledge and skills ${ }^{(9-11,13)}$. Sending students unprepared to an ICU also affects learning by increasing anxiety and poses a risk for both student and patient safety ${ }^{(2,13)}$. In this study, the students stated that the need for care of the patients and nursing interventions such as oral care and aspiration affected them emotionally. The students' statements revealed that they experienced higher level of anxiety. One of the students, for example, said, "I helped the nurse to perform oral care. The patient was intubated. I was so nervous that I would hurt the patient, and the patient's unconscious state made me even more tense". Similarly, in a study by Bay et al. ${ }^{(3)}$, one of the students described her nervousness during the care of a patient who underwent craniectomy by saying "I have not cared for a patient with tracheostomy and bone loss before. I do not know how to give care in such a situation. I am overwhelmed". Also, in other similar studies, students mentioned their feelings of fear and panic caused by critically ill patients with a poor general condition by saying, "Patients who I thought would not get better made me feel bad psychologically" (11) and "When I first went to the ICU, I was shocked. Almost all of the patients were intubated and they lied with eyes closed" (4). Bay et al. ${ }^{(3)}$ found that students were afraid of not knowing how to intervene, not being able to maintain the patient's safety and harming the patient in cases such as seizures accompanied by tonic and clonic contractions while caring for the neurosurgical patient, and that the vulnerability of patients affected them. It is vital to reduce the anxiety of students as excessive stress and anxiety affect their learning ability negatively ${ }^{(2,11,13)}$. Swinny and Brady ${ }^{(2)}$ reported that students who are well prepared for clinical training quickly adapt to the planning process of critical patient care and are more willing to provide care with nurses. Therefore, before sending students to the neurosurgical ICU, they should be informed about the care interventions applied in this unit and patients' conditions, they should be introduced to the nurse they will work with, and if possible, they should be accompanied by the same nurse, especially in short-term training.
Another important experience that the training in the critical care unit brings to the student is that this training lets students give care to a terminal patient $(2,3,8,13)$. Death is a life experience that student nurses encounter rarely ${ }^{(2,3,13)}$. This experience causes student nurses to experience grief ${ }^{(3,4,11)}$ and to question whether the patient's death has been caused by any inadequacy in treatment or care ${ }^{(3)}$. In our study, it was determined that some of the students witnessed the death of a patient in the ICU and this experience affected them emotionally. Some of the students mentioned their feelings of grief and despair saying, "My patient got worse and worse before my eyes and there was nothing I could do", "We lost my patient and I was shocked" and "The struggle for life and death of my patient affected me deeply". In a similar study, after the death of an aneurysmal subarachnoid hemorrhagic patient, one of the students said that she asked herself, "Could I have done anything to prevent this patient's death?" and added that this problem with no answer upsetted her ${ }^{(3)}$. In other similar studies, students who lost their patients mentioned deep sorrow saying, "I wanted to die after the death of my 25-year-old patient" (11) and "Seeing a patient's death affected me a lot and I did not go to the ICU for two days" (4). These findings, which also support the results from our study, suggest that witnessing a patient's death is a distressing experience for student nurses. The nurse and the instructor should turn this sad experience into a positive learning experience ${ }^{(2,3,13)}$. In this process, it is crucial that student nurses learn the nursing care to be given during and after the terminal phase, communication in this phase and how to break the news of a patient's death to his or her family ${ }^{(2,3)}$. The fact that one of the students in our study, who lost her patient said, "Together with the nurse, I removed the patient's clothes and cleaned her body. It was the first time that I had ever approached a dead person. It was a distressing experience, but I learned a lot" indicates how instructive this process is for students as well as the significance of this experience.

One of the main issues that students experience in ICUs is lack of effective communication. Although effective communication between the patient and the nurse is an important part of quality care in ideal terms, students may have difficulty communicating with critical care patients ${ }^{(2,11-13)}$. Our results showed 
that during their clinical training in the neurosurgical ICU, the students had difficulty in communicating with unconscious patients and conscious intubated patients, attempted to establish eye communication with intubated patients, and felt inadequate due to communication problems. The fact that one of the students said, "I tried to communicate by calling their names. I had difficulty particularly with patients connected to the respirator. The nurses communicated with these patients in the same way... by calling out their names" is important as it showed that they had problems in communicating with patients and they could not use nurses' help in solving these problems. Similarly, Vatansever and Akansel (4) showed that the students thought some nurses in the ICU did not employ appropriate communication techniques. Also, in a study by Taştan et al. ${ }^{(11)}$, the students had problems communicating with critical patients who were unconscious or unable to speak and described the feeling of inadequacy caused by this problem saying, "I tried to understand what the patient with tracheostomy wanted from his lip movements, but I could not. At that moment I felt inadequate and upset". Both the literature and this study showed that student nurses know the importance of communicating with patients who are unconscious or unable to speak, but they do not know how to do this. Before students are sent to this unit, they should be informed about how to communicate with unconscious patients, conscious but intubated patients, and their communication skills should be developed through training techniques such as role-playing ${ }^{(2)}$. In a qualitative study, one student said, "I had difficulties in communicating with unconscious patients. I wish this topic had been emphasized more in lessons" (11), which shows the significance of this issue. The instructor and the nurse should be role models in communicating with unconscious patients and they should support students.

Clinical training is not only an application carried out with the instructor, but it is also a learning experience supported by the cooperation of all health professionals, especially experienced clinical nurses $(2,6,7,12$ 14). The students in our study stated on their first day that they considered the nurses as being knowledgeable and experienced, but they thought the nurses did not give adequate care to patients. For example, some of the students said, "The nurses were knowledgeable, but they had poor communication with patients" and "There were patients in need of care, but the nurses did not provide health care adequately". These statements are important in terms of demonstrating that the students had both positive and negative thoughts about the ICU nurses on the first day of their clinical training and they were frustrated. This may be because the students had been in the ICU environment for the first time, they had no knowledge of intensive care nursing and critical patient care, and the nurses were not able to cooperate due to their heavy workload. In similar studies, it was determined that the negative attitudes of nurses $(1,7,9,10)$, their inability to reserve enough time for the students due to their heavy workload ${ }^{(4)}$ and their failure to support the students in solving the problems they experienced ${ }^{(5,9)}$ negatively affected their clinical training. Research also showed that those nurses who made students feel as if they were not welcomed in the unit, did not give students responsibility for patient care and perform duties other than their roles and responsibilities which negatively affect clinical training ${ }^{(7)}$. Having experienced nurses in the learning environment who can be role models reduces fear and anxiety that students could experience, improves teamwork and communication skills, and boosts their professional self-esteem ${ }^{(2,3,8,11,13)}$. For this reason, the competence of nurses to be role models should be taken into consideration in the selection of clinical training environment as well as the suitability of the environment.

Our results showed that the students' negative thoughts and perceptions about the nurses changed by the end of the clinical training, and they thought nurses were professional and motivating and they possessed critical thinking and empathy skills. These statements show that interaction in the training process and the learning realized with the contribution of nurses positively affect students. A previous study showed that the clinical experience of some (48.1\%) students who could not get feedback about their clinical performance, was negatively affected (9), which highlights the importance of interaction and sharing in student learning. The clinical training process, in which students acquire knowledge and skills, is actually a dynamic process where nurses spend time and effort to teach, update their knowledge, 
share their experiences and contribute to their responsibility of training professionals ${ }^{(2,3,8,14)}$. Hansen et al. ${ }^{(14)}$ stated that the ICU nurses in their study considered the time they spent with students as motivating. In another similar study, the nurses were found to be well aware of their role in training nursing students, and they said, "I love to share and teach my experiences, and I influence the future" and "we know that nursing students are our future" (8).

The use of knowledge and skills gained at school in clinical settings ${ }^{(5,7,13)}$ increases student self-esteem and self-confidence ${ }^{(2,8-10)}$, and strengthens their hopes that they will become professional nurses ${ }^{(8,13)}$. ICUs are effective clinical settings in translating theoretical knowledge into practice and letting students gain professional confidence $(2,4,11,13)$. Kandeel and Ahmed ${ }^{(9)}$ showed that clinical training in ICU improves students' clinical skills and increases their selfconfidence in meeting critical patient's care needs. Similarly, in our study, the majority of the students stated that clinical training in the neurosurgical ICU increased their professional knowledge and that they managed to reflect their theoretical knowledge on patient care practices in this process. The students also stated that clinical training in this unit increases their self-confidence and professional knowledge, saying, "Giving care without any help increased my self-esteem" and "My professional knowledge has increased." Student nurses in other similar studies emphasized the impact of clinical training in ICU on their self-confidence, professional knowledge and skills, saying, "My most intense feeling at the end of the practice was self-confidence", "At first, I didn't even know how to turn off the ventilator alarm, but last week the nurse gave me patient care responsibility" (11) or "Working here made me understand what nurses actually did" (4). Also, another similar study showed that by means of clinical training at ICU, the students realized that being a nurse is not only limited to care, but requires much more responsibility than generally thought ${ }^{(12)}$.

The problems encountered during clinical training and the experiences gained affect students' view of the profession, and negative experiences can cause them to move away from the profession ${ }^{(1,5,7,13)}$. The students in our study mentioned the change that occurred in them after clinical training in the neuro- surgical ICU by saying, "I have understood how important my profession is", "I love my job more now" and "It was the first time I genuinely wanted to be a nurse." These statements are important in terms of showing that clinical training in the neurosurgical ICU positively affects the attitude towards the profession. In fact, in our study, these positive feelings caused the majority of the students to want to work in this unit after graduation. In addition, the majority of the students stated that they thought this unit was an essential clinical area for nursing education. Some other similar studies showed that positive ICU experiences increase students' selfconfidence ${ }^{(7)}$ and increased students' willingness to work in ICU after graduation ${ }^{(4,11)}$. Also, Çelik and Veren ${ }^{(1)}$ found that students who leave ICUs contently, who are satisfied with the care they give to critical patients and think that these units are necessary for clinical training want to work in these units after graduation. As a result, both the literature and this study suggest that clinical training experience could be effective in students' preference for employment after graduation. Therefore, the feedback of students regarding their clinical training should be taken into consideration and if students have any problems about the clinical settings that negatively affect their perceptions of the nursing profession and its roles and responsibilities, these problems should be eliminated.

\section{CONCLUSION and RECOMMENDATIONS}

The results derived from this study showed that the students considered the neurosurgical ICU as an important and useful clinical environment in nursing education and their clinical experience was positively affected by the supportive atmosphere in this environment. In this environment, the students applied different nursing interventions, observed the care given to patients in their terminal phase, and learned about the roles and responsibilities of an intensive care nurse. An important result obtained from this study is that some of the students stated that their views on the profession changed positively and their professional self-confidence increased following their experience in this unit. On the other hand, despite these positive results, it was determined that some of the students experienced severe anxiety in this unit and did not want to work in this 
unit after graduation. This may be due to the fact that the students were only in their second year of study and had little clinical experience, received clinical training in the ICU for the first time and they were sent to this unit unprepared. The neurosurgical ICU, like other ICUs, is one of the areas where newly graduated nurses are frequently employed. For this reason, it is vital to reduce the number of negative experiences peculiar to this unit. Informative training sessions with real-life cases, the presence of an accompanying lecturer on the first day of ICU, and the supportive and motivating approach of nurses could reduce anxiety and traumatic experiences experienced by student nurses.

Author Contributions: Literature review: SY, GAU; Designing the Research: SY, GAU; Data Collection: SY; Processing of Data: SY; Data Analysis: SY, GAU; Writing the Research: SY, GAU; Critical Review: SY, GAU; Preparing for Publication: SY, GAU.

Ethics Committee Approval: T. C. Necmettin Erbakan University Meram Faculty of Medicine, Pharmaceuticals and Non-Medical Device Researches Ethics Committee approval was received (1.6.2018/1389).

Conflict of Interest: The authors declare that they have no conflict of interest.

Funding: This research received no specific grant from any funding agency in the public, commercial, or not-for-profit sectors.

Informed Consent: The students who participated in this study were informed about the aim of the study, they were explained that participation in the study was voluntary, and their verbal and written consent was obtained.

Etik Kurul Onayı: T.C. Necmettin Erbakan Üniversitesi Meram Tıp Fakültesi İlaç ve Tıbbi Cihaz Dışı Araştırmalar Etik Kurul onayı alındı (1.6.2018/1389). Çıkar Çatışması: Yazarlar çıkar çatışması olmadığını beyan etmişlerdir.

Finansal Destek: Bu araştırma kamu, ticari veya kar amacı gütmeyen sektörlerdeki hiçbir fon ajansından özel bir hibe almamıştır.

Hasta Onamı: Bu çalışmaya katılan öğrenciler araştırmanın amacı hakkında bilgilendirilmiş, araştırmaya katılımın gönüllü olduğu, sözlü ve yazılı onamları alındığı açıklanmıştır.

\section{REFERENCES}

1. Çelik S, Veren F. Öğrenci hemşirelerin mezuniyet sonrasında yoğun bakım ünitelerinde çalışma hakkındaki görüşleri. Yoğun Bakım Hemşireliği Dergisi. 2009;13(2):63-8.

2. Swinny B, Brady M. The benefits and challenges of providing nursing student clinical rotations in the intensive care unit. Crit Care Nurs Q. 2010;33(1):60-6. [CrossRef]

3. Bay EH, Binder C, Lint C, Park S. Mentoring the next generation of neuroscience nurses: a pilot study of mentor engagement within an academic-service partnership. J Neurosci Nurs. 2015;47(2):97-103. [CrossRef]

4. Vatansever N, Akansel N. Intensive care unit experience of nursing students during their clinical placements: a qualitative study. International Journal of Caring Sciences. 2016;9(3):1040-8.

5. Karadağ G, Parlar Kılıç S, Ovayolu NM, Ovayolu Ö, Kayaaslan $\mathrm{H}$. Öğrenci hemşirelerin klinik uygulamada karşılaştıkları güçlükler ve klinik hemşireler hakkındaki görüşleri. TAF Preventive Medicine Bulletin 2013;12(6):665-72. [CrossRef]

6. Dikmen Aydın Y, Şahin Orak N, Gürkan A, Aslan G, Demir F. Hemşirelik öğrencilerinin klinik eğitimleri sırasında hemşirelerden aldığı desteğin değerlendirilmesi. JAREN. 2017;3(3):109-15. [CrossRef]

7. Najafi Kalyani M, Jamshidi N, Molazem Z, Torabizadeh C, Sharif F. How do nursing students experience the clinical learning environment and respond to their experiences? A qualitative study. BMJ Open. 2019;9(7):e028052. [CrossRef]

8. Goldin M, Kautz DD. Nurturing nursing students during intensive care unit clinical practicum. Dimens Crit Care Nurs. 2010;29(5):238-40. [CrossRef]

9. Kandeel NA, Ahmed HH. Nursing students' perception of their clinical practice in intensive care units: a study from Egypt. Journal of Nursing Education and Practice. 2019;9(7):101-8. [CrossRef]

10. Alasad JA, Ahmad MM, Tabar NA, Ahmad H. Nursing student's experiences in critical care course: a qualitative study. J. Intensive \& Crit Care. 2015;1(1):1-6. [CrossRef]

11. Tastan S, Iyigun E, Ayhan $\mathrm{H}$, Hatipoglu S. Experiences of Turkish undergraduate nursing students in the intensive care unit. Collegian. 2015;22(1):117-23. [CrossRef]

12. Câmara AG, Silva AKM da, Souza AAM de, Ribeiro KRB. Experience of nursing students in intensive care unit: an experience report. Journal of Nursing UFPE on line. 2012;6(10):2582-5. [CrossRef]

13. Williams E, Palmer C. Student nurses in critical care: benefits and challenges of critical care as a learning environment for student nurses. Nurs Crit Care. 2014;19(6):310-5. [CrossRef]

14. Hansen BS, Gundersen EM, Bjørnå GB. Improving student supervision in a Norwegian intensive care unit: a qualitative study. Nurs Health Sci. 2011;13(3):255-61. [CrossRef]

15. Creswel JW. Qualitative Inquiry and Research Design: Choosing Among Five Approaches. $2^{\text {nd }}$ ed. India: Sage Publications India Pvt. Ltd; 2007. p. 53-221.

16. Erdoğan S. Nitel Araştırmalar. İçinde: Erdoğan S, Nahcivan N, Esin MN, edt. Hemşirelikte Araştırma: Süreç, Uygulama ve Kritik. İstanbul: Nobel Tıp Kitabevleri; 2014, 131-165.

17. Arastaman G, Öztürk Fidan I, Fidan T. Nitel araştırmada geçerlik ve güvenirlik: kuramsal bir inceleme. YYÜ Eğitim Fakültesi Dergisi. 2018;15(1):37-75. [CrossRef] 